BOYER, Véronique. Expansion évangélique et migrations en Amazonie brésilienne. La renaissance des perdants. Paris: IRD e Karthala, 2008, 232pp.

\title{
MigRaÇÃO E SEGMENTAÇÃO EVANGÉLICA: AS DINÂMICAS DE UM PROCESSO
}

\author{
Andréia Vicente da Silva
}

Este livro é um estudo sobre a presença dos evangélicos na região amazônica que sinaliza para a estreita relação entre a migração de populações e o movimento de expansão da religião. Mais especificamente, a autora propõe que existe uma complementaridade entre a dinâmica de mobilidade da população e a de segmentação institucional religiosa.

Boyer parte da constatação que a circulação das populações na Amazônia não é circunstancial. Diversos fatores demandam a mudança de lugar, desde os ciclos de cheia e vazante dos rios, às dificuldades econômicas, até as constantes políticas de ocupação territorial implementadas pelo governo federal brasileiro. Foi em um contexto de intensa circulação populacional que chegaram os primeiros missionários europeus no século XIX. Neste primeiro momento, a palavra bíblica circulou a partir da ação de missionários e evangelistas, homens sem recursos e com projetos individuais, que migravam constantemente "carregando" consigo a nova religião. Posteriormente, outros modos de circulação irão potencializar, neutralizar ou dificultar o duplo circuito.

Nesse sentido, estamos diante de uma obra antropológica que não se furta em propor uma imagem panorâmica de um processo regional mais amplo. Segue com um rigor etnográfico de aporte multisituado em diferentes regiões dos Estados do Acre, Amazonas, Pará e Rondônia, em uma pesquisa de campo realizada por um longo período entre os anos de 1996 e 1999. Véronique Boyer organiza seu material segundo uma "história-ficcional" cujo ponto de partida é a chegada dos missionários e famílias em cidades dominadas pelo catolicismo. Numa progressão temporal, os conflitos vão se desdobrar até que as igrejas evangélicas ganhem espaço em territórios antes hostis, e acabem compondo, junto com outras religiões, o quadro das ofertas religiosas locais.

No primeiro capítulo, a autora retoma a história da chegada dos protestantes europeus ao Brasil via projetos institucionais e com recursos financeiros de terceiros. Ocorre aqui a primeira justaposição bem sucedida da mensagem pregada 
por esses homens com a realidade migratória da população. Quando a mensagem evangélica atinge os indivíduos migrantes, a "boa nova" começa a se movimentar com eles, que se deslocam pelo território nas inúmeras frentes de trabalho. No segundo capítulo, "Tempos de Conflito", a autora nos leva a conhecer Vila do Castelo, uma pequena cidade em Belém do Pará que foi fundada de acordo com o modelo de organização sócio-religioso desenvolvido a partir da Décima Conferência do Episcopado Latino Americano. A liderança estabelecida nessa cidade articula a fé religiosa e a vida cotidiana com forte referência católica. Vila do Castelo é um bom modelo para a compreensão do modo de imposição dos evangélicos quando o catolicismo é predominante. Se num primeiro momento os católicos monopolizam as posições de comando político e econômico do lugar dominando o cotidiano das cidades, isso vai se modificando a partir das conversões. A emergência do novo lugar está diretamente relacionada à autoridade de uma "verdade" que salva. As disputas travadas em diversos campos do cotidiano são reconhecidas como conflitos entre os que são "daqui" (católicos e fundadores) e os "de fora" (termo reconhecidamente associado aos evangélicos).

Em "Tempos de Agregação" vemos essas querelas se acalmarem à medida que os evangélicos vão dividindo posições antes monopolizadas pelo catolicismo. Um bom exemplo disso é a realização dos rituais católicos pelos pastores e líderes evangélicos. É o caso da promessa que é paga com um voto evangélico num culto realizado por um dirigente. Aproveitando os espaços deixados pelos padres, os pastores e dirigentes vão conseguindo novas adesões e se fixando nas vilas e cidades.

É interessante observar como a autora afirma variadas possibilidades de adesão a partir das diferentes religiosidades. Há uma série de lacunas abertas que favorecem o trânsito dos indivíduos na multiplicidade do campo religioso brasileiro. Por exemplo, hábitos de vestimenta e auto-apresentação, cuja adesão é rigorosamente controlada pelos pastores e congregandos, podem ser flexibilizadas em função de um alargamento temporal. De um modo geral, embora o indivíduo compreenda a conversão evangélica como única possibilidade de salvação, ele pode utilizar um tempo "impreciso" para realizar as adequações exigidas. Por vias como essa, a religiosidade ascética torna-se mais acessível e negociável, uma vez que é possível circular entre diferentes denominações.

Nos dois capítulos seguintes, a autora se dedica à análise das diferentes carreiras de lideranças evangélicas e à fundação de novas igrejas. A figura do evangelista é central na argumentação, pois é a partir desse personagem que a palavra é divulgada. Ele é um elemento de continuidade da propagação das mensagens indo a todos os lugares e estabelecendo inicialmente as congregações. Véronique Boyer usa as histórias de três homens, cada um deles numa posição - evangelista, dirigente e pastor - para demonstrar como esses indivíduos reconstroem suas trajetórias após a conversão a partir de uma narrativa que 
toma como ponto de partida seus lugares de poder. $O$ evangelista tem em sua fala o tema da migração por excelência, ao mesmo tempo em que evidencia a falta de recursos e as dificuldades enfrentadas numa vida de dedicação não custeada pelas lideranças centrais das igrejas.

Aspectos sociais contextuais também são lembrados como facilitadores da adesão ao modelo de "missão" evangélica. Nas igrejas que percorreu, a autora encontrou uma realidade de pobreza e desemprego, de doenças e abandonos, constituindo um amálgama de problemas cotidianos que são enfrentados pelos pastores, missionários e dirigentes. Há sempre uma esperança de que a conversão propiciará uma mudança completa na condição de vida, porém, a ruptura sociológica com o passado dificilmente tem o impacto de ruptura radical desejado. Entre os efeitos sociais mais fortes de ruptura, a autora destaca a construção dos novos lugares de liderança por homens e mulheres e dos novos modos de habitação do lugar, com parâmetros mais claros sobre a vida ética. Frequentemente, quando o missionário funda uma igreja e fixa uma congregação, ele possivelmente servirá de exemplo e parâmetro para os freqüentadores daquele local.

O tema da emancipação das igrejas é o assunto do capítulo seis. Boyer faz questão de esclarecer que embora existam divergências doutrinárias e teológicas entre os diferentes líderes de igrejas, a dissidência será sempre explicada a partir da relação com o sagrado. Isso pode ser feito de várias maneiras, a saber: há no discurso evangélico um apelo ao desenvolvimento da carreira espiritual, o que muitas vezes não é possível dentro de igrejas já formadas e com lideranças nítidas. Neste sentido, as portas estão abertas para a separação a partir de um discurso de não criticar a liderança alheia, mas de justificar a cisão como uma nova oferta diferente daquelas já existentes. "As igrejas não têm meios de conter a diversificação do campo evangélico" (:171), revela a autora, tanto porque abandonam os indivíduos no campo, sem apoio e sem recursos, quanto porque o apelo à missão é parte integrante do sistema evangélico.

Com esta passagem, somos introduzidos aos dilemas contemporâneos da expansão evangélica na Amazônia. Se as primeiras missões promoveram um enfrentamento do catolicismo, agora, a possibilidade de "cativeiro" se refaz a partir das lideranças das igrejas evangélicas estabelecidas. Isto leva a autora a remeter ao debate sobre "cativeiro" na região, pois constitui-se uma dinâmica cíclica de poder, que parece se fechar sobre si. Atualmente, as grandes convenções e ministérios de culto tentam ocupar o lugar de "dominadores" anteriormente atribuído aos católicos. Mesmo que exista uma multiplicação de igrejas, isto ocorre de modo a formar grandes conjuntos institucionais, os quais são governados com mão de ferro por uns poucos pastores e líderes.

Em seguida, no capítulo oito, Boyer retoma os estudos do campo religioso brasileiro buscando observar quais são os principais aspectos investigados pelos antropólogos e como estes pontos são compreendidos no discurso dos religiosos. 
Existe uma herança de pesquisas no Brasil que separa as religiões afro-brasileiras, o catolicismo e os movimentos evangélicos. Ao contrário do que vem sendo repetidamente afirmado, Véronique Boyer vê o campo evangélico como parte de um sistema múltiplo de religiosidade no Brasil, com um sistema compartilhado de traços e trocas entre religiões. Citando casos e experiências coletadas no campo, ela argumenta a favor de uma abordagem sincrética, onde os contatos entre as religiões são mais fundamentais que seus ideais de pureza.

Trata-se de uma obra instigante e muito bem documentada etnograficamente. Entretanto, a idéia de apresentar o conjunto como uma "espécie de ficção" parece simultaneamente ousado demais e ilusório. Na verdade, a ficção que autora oferece ao leitor estrutura-se como uma genealogia hipotética para as religiões na região. Nesta ficção, o crescimento religioso segue a mesma disposição temporal do mapa amazônico, evidenciando uma evolução que se dá a partir de um ponto comum que segue a mesma rota das políticas de povoamento e migração. Ora, pode-se dizer que a evolução da ficção é a mesma do mapa, que nada mais é que a ilusão de outra convenção. Se as duas ficções são convencionais e se ratificam, fica a questão sobre onde ficam todas aquelas histórias heterodoxas e pouco convencionais de um processo social plural e multidirecional.

Andréia Vicente da Silva (deiavicente@gmail.com) Doutoranda em Ciências Sociais do Programa de Pós-Graduação em Ciências Sociais da Universidade do Estado do Rio de Janeiro. 